\title{
Activación alcalina de cenizas volantes. Relación entre el desarrollo mecánico resistente y la composición química de la ceniza
}

\section{Alkali-activated fly ash. Relationship between mechanical strength gains and initial ash chemistry}

\author{
G. Kovalchuk ${ }^{(*)}, \underline{\text { A. Fernández-Jiménez }}{ }^{(*)}$ y A. Palomo(**)
}

Recepción/Received: 12-IX-06

Aceptación/Accepted: 7-III-07

Publicado online/Online publishing: 28-V-08

\section{RESUMEN}

Las cenizas volantes activadas alcalinamente constituyen la base de una nueva generación de cementos con muy interesantes propiedades mecánicas, adherentes y durables (a veces incluso mejores que las de los cementos Portland tradicionales). Adicionalmente el desarrollo de estos cementos podría contribuir a mitigar las emisiones de $\mathrm{CO}_{2}$ a la atmósfera, ya que el material base de los mismos puede estar formado por subproductos industriales. En la presente investigación se realizó un estudio para determinar la influencia de la composición de los materiales iniciales (ratios $\mathrm{SiO}_{2} / \mathrm{Al}_{2} \mathrm{O}_{3}$ y $\mathrm{Na}_{2} \mathrm{O} / \mathrm{Al}_{2} \mathrm{O}_{3}$ ) en las propiedades mecánicas y en la naturaleza y composición de los productos de reacción. Los resultados obtenidos indican que no existe una relación lineal de dichas ratios con las resistencias mecánicas, sino que existen unos valores óptimos, por encima y debajo de los cuales las resistencias mecánicas disminuyen. En el caso concreto de las ratios estudiadas en el presente trabajo estos valores serian: $\mathrm{SiO}_{2} / \mathrm{Al}_{2} \mathrm{O}_{3}=4,0$ y Na $2 \mathrm{O} / \mathrm{Al}_{2} \mathrm{O}_{3}=1,0$ (relaciones molares)

Palabras clave: ceniza volante, activación alcalina, cementos alcalinos, zeolitas.

\section{SUMMARY}

Alkali-activated fly ash is the primary component of a new generation of high-strength, durable binders with excellent mechanical properties and durability (on occasion bettering traditional Portland cement performance). Moreover, development of these cements may contribute to mitigating $\mathrm{CO}_{2}$ emissions, since the base material is an industrial by-product. The present study was conducted to determine the effect of the composition of the initial materials $\left(\mathrm{SiO}_{2} / \mathrm{Al}_{2} \mathrm{O}_{3}\right.$ and $\mathrm{Na}_{2} \mathrm{O} / \mathrm{Al}_{2} \mathrm{O}_{3}$ ratios) on the mechanical properties, nature and composition of the reaction products. The results obtained indicate that there is no linear relationship between these ratios and mechanical strength, but rather a series of optimal values above and below which strength declines. In the specific case of the ratios studied in the present paper, these values were: $\mathrm{SiO}_{2} / \mathrm{Al}_{2} \mathrm{O}_{3}=4.0$ and $\mathrm{Na}_{2} \mathrm{O} / \mathrm{Al}_{2} \mathrm{O}_{3}=1.0$ (molar ratios).

Keywords: Fly ash, alkali activation, alkaline cements, high-strength cements, zeolites.

\footnotetext{
(*) Scientific Research Institute on Binders and Materials, (Kyiv, Ukraine).

(**) Instituto de Ciencias de la Construcción Eduardo Torroja (CSIC) (Madrid, España).
} 


\section{INTRODUCCIÓN}

Una de las principales tareas que ha de abordar hoy día la comunidad científico-técnica del campo de los materiales es la resolución de los problemas energéticos y ambientales que origina la masiva producción de cemento Portland. Todos somos conscientes de la necesidad de incorporar al proceso constructivo materiales cuya fabricación o procesado no conlleve asociada la emisión a la atmosfera de grandes cantidades de $\mathrm{CO}_{2}$. Además, siempre queda el reto pendiente de mejorar con el uso de nuevos materiales las prestaciones que el cemento Portland ofrece hoy día; muy buenas en términos generales.

Los cementos alcalinos, inicialmente propuestos por Glukhovskiy en 1957 (1,2), son conglomerantes básicamente formados por dos componentes: un material pulverulento de naturaleza aluminosilicica, y un activador alcalino. Los procesos de reacción que se llevan a cabo durante la "activación alcalina", han de considerarse como un conjunto de transformaciones complejas del sólido de partida que en su estadio final conducen a una estructura condensada con propiedades cementantes (1-8).

Las peculiaridades composicionales de los cementos alcalinos es tal que en función de éstas se pueden obtener diferentes tipos de materiales cementantes. En este contexto, los cementos alcalinos podrían inicialmente dividirse en dos grandes grupos (4): En el primero de estos grupos el principal producto de reacción es un gel de aluminosilicato alcalino de naturaleza similar a la de las zeolitas; en el segundo grupo, los principales productos de reacción son silicatos hidratados de calcio y magnesio. Este segundo grupo de materiales cementantes ha sido ya aplicado con éxito a nivel industrial (8). Sin embargo los cementos alcalinos que conforman el primer grupo, a pesar de su gran potencial (económico y técnico), no han sido todavía suficientemente explorados. Quizás se deba esto a que por el momento sólo un pequeño grupo de materias primas (básicamente cenizas volantes y metacaolin) ha demostrado capacidad suficiente para ser transformadas de forma eficaz en cementos resistentes. En cualquier caso, los cerca de 1.000 millones de toneladas de ceniza que se producen en el mundo anualmente, son un buen argumento para discutir en torno a su competitividad como material base de fabricación de una nueva generación de cementos alcalinos.

Desde 1974 (9-10), pero fundamentalmente desde finales de los años 90 (11-22), algunos grupos de investigación han prestado especial atención a los sistemas cementantes basados en la activación alcalina de cenizas volantes. Las investigaciones más recientes han demostrado que:

\section{INTRODUCTION}

One of the tasks presently incumbent upon the construction materials scientific-technical community is the solution of the energy and environmental problems generated by the production of vast quantities of Portland cement. The entire community, and indeed the public at large, is aware of the need to encourage the use of construction materials that can be manufactured or processed without emitting huge amounts of $\mathrm{CO}_{2}$. Another challenge still outstanding is the improvement of the present generally good performance of Portland cement by blending it with new materials.

Alkaline cements, initially proposed by Glukhovskiy in 1957 $(1,2)$, are binders essentially consisting in two components: a powdery aluminosilicate-based material and an alkaline activator. The reactions taking place during alkali activation constitute a series of complex transformations that convert the initial solid into an end product with a condensed structure and cementitious properties (1-8).

Among the peculiarities of alkaline cements is the fact that depending on their composition, they yield different types of cementitious materials. In this context, alkaline cements may be initially divided into two major groups (4): in the first, the main reaction product is an alkaline aluminosilicate gel similar to zeolites in nature; in the second, the main reaction products are hydrated calcium and magnesium silicates. This second group of cementitious materials has been successfully used on an industrial scale (8). Despite their huge (economic and technical) potential, however, the alkaline cements in the first group have not been sufficiently explored. This may be due to the fact that for the time being only a short list of prime materials (essentially fly ash and metakaolin) have proved to be effectively transformable into strong cements. In any event, with nearly one billion tonnes produced yearly world-wide, fly ash may be clearly contended to be a competitive commodity for producing a new generation of alkaline cements .

Since 1974 (9-10) but essentially since the late nineteen nineties (11-12), some research groups have devoted special attention to cementitious systems based on the alkali activation of fly ash. The most recent research has shown that: 
- Con estos materiales se pueden alcanzar resistencias mecánicas a la compresión superiores a los $80 \mathrm{MPa}$ tras un corto periodo de tiempo de curado térmico ( 8 horas a $\left.60^{\circ} \mathrm{C}\right)(14,23,24)$.

- Además de unas excelentes propiedades mecánicas, el material posee una excelentes propiedades durables; especialmente en lo que se refiere a su resistencia a agresivos ácidos, reacción árido álcali, etc. $(4,25)$.

- Los hormigones elaborados con ceniza volante activada alcalinamente (sin OPC) presentan con respecto a los hormigones tradicionales un comportamiento similar e incluso mejor en aspectos tales como: la retracción o la adherencia matriz-armadura de refuerzo (16).

- Son materiales con una excelente capacidad de fijar elementos tóxicos $(26,27)$.

En definitiva, el conocimiento profundo de los mecanismos que controlan la formación de los productos cementantes durante el proceso de activación alcalina de las cenizas volantes se ha convertido en un requisito necesario a través del cual será posible determinar la interrelación "composición de partida - condiciones de curado nanoestructura - propiedades".

El presente trabajo incide específicamente en el papel que juega la composición del sistema de partida en el desarrollo de resistencias mecánicas del producto final.

\section{PROCEDIMIENTO EXPERIMENTAL}

El desarrollo de la investigación se llevó a cabo esencialmente con una ceniza volante del tipo $F$ (clasificación ASTM) procedente de una central térmica del norte de España (ver Tabla 1). Dicha ceniza tiene un $78,86 \%$ de partículas con tamaño inferior a $45 \mu \mathrm{m}$ y su superficie específica es de 202 m²/kg. Además para preparar la
- Compressive strength values of over $80 \mathrm{MPa}$ can be obtained with these materials after brief ( 8 hours at 60 $\left.{ }^{\circ} \mathrm{C}\right)$ thermal curing $(14,23,24)$.

- In addition to its excellent mechanical properties, the material is particularly durable and highly resistant to aggressive acids, the aggregate-alkali reaction and so on $(4,25)$.

- Concrete made with alkali-activated fly ash (without $O P C)$ performs as well as traditional concrete and even better in some respects, such as shrinkage or matrixreinforcing steel bonding (16).

- These materials are extremely effective for fixing toxic elements $(26,27)$.

In short, a thorough understanding of the mechanisms governing the formation of cementitious products during the alkali activation of fly ash has become an imperative in the determination of "initial composition - curing conditions - nanostructure - properties" inter-relationships.

The present paper focuses specifically on the role of the composition of the initial system in the development of end product mechanical strength.

\section{EXPERIMENTAL PROCEDURE}

The research was conducted essentially with a type $F$ fly ash (ASTM classification) produced by a coal-fired steam power plant in northern Spain (see Table 1). The $<45 \mu \mathrm{m}$ particle fraction accounted for $78.86 \%$ of this ash, whose BET specific surface was $202 \mathrm{~m}^{2} / \mathrm{kg}$. The activator was a sodium silicate (waterglass or Wg) solution with a silica

Tabla 1 / Table 1

Composición química de los principales productos sólidos Chemical compositions of the main solid constituents

\begin{tabular}{|c|c|c|c|c|c|c|c|c|c|c|c|}
\cline { 2 - 9 } \multicolumn{1}{c|}{} & $\mathbf{S i O}_{\mathbf{2}}$ & $\mathbf{A l}_{\mathbf{2}} \mathbf{O}_{\mathbf{3}}$ & $\mathbf{F e}_{\mathbf{2}} \mathbf{O}_{\mathbf{3}}$ & $\mathbf{C a O}$ & $\mathbf{M g O}$ & $\mathbf{S O}_{\mathbf{3}}$ & $\mathbf{N a}_{\mathbf{2}} \mathbf{O}$ & $\mathbf{K}_{\mathbf{2}} \mathbf{O}$ & ${ }^{\mathrm{b}} \mathbf{I} . \mathbf{R}$. & ${ }^{\mathbf{C}}$ L.O.I. & Total \\
\hline $\begin{array}{c}\text { Ceniza volante/ } \\
\text { Fly ash }\end{array}$ & $\begin{array}{c}54.42 \\
\mathrm{a}(45.05)\end{array}$ & 26.42 & 7.01 & 3.21 & 1.79 & 0.01 & 0.59 & 3.02 & 0.78 & 2.19 & 99.44 \\
\hline $\begin{array}{c}\text { Humo de } \\
\text { silice/silica } \\
\text { fume }\end{array}$ & 92.02 & 0.70 & 0.39 & - & - & - & - & - & - & 6.28 & 99.45 \\
\hline
\end{tabular}

a Silice reactiva determinada segun la norma española UNE 80-225-93 / Reactive silica determined as indicated in spanihs standard Un 80-225-93.

b I.R. - Residuo Insoluble / Insoluble Residue.

c L.O.I. - perdida por calcinación / loss on ignition. 
disolución activadora se utilizó una disolución de silicato sódico (waterglass o $\mathrm{Wg}$ ) con un módulo de sílice de 3,35 , con una densidad de $1.350 \mathrm{~kg} / \mathrm{m}^{3}$ y con la siguiente composición porcentual $\mathrm{Na}_{2} \mathrm{O}=8,2 \%, \mathrm{SiO}_{2}=27 \%$ and $\mathrm{H}_{2} \mathrm{O}=64,8 \%$. Este reactivo fue suministrado por PANREAC SA. modulus of 3.35 , a density of $1,350 \mathrm{~kg} / \mathrm{m}^{3}$ and the following percentage composition: $\mathrm{Na}_{2} \mathrm{O}=8.2 \%, \mathrm{SiO}_{2}=27 \%$ and $\mathrm{H}_{2} \mathrm{O}=64.8 \%$. This reagent was supplied by PANREAC S.A.

Tabla 2 / Table 2

Composición y resistencias mecánicas de las muestras estudiadas Systems studied: composition and mechanical strength

\begin{tabular}{|c|c|c|c|c|c|}
\hline \multirow{2}{*}{$\begin{array}{c}\text { Muestra/ } \\
\text { Sample }\end{array}$} & \multicolumn{2}{|c|}{$\begin{array}{c}\text { Relación molar/ } \\
\text { Molar ratio }\end{array}$} & \multirow{2}{*}{$\begin{array}{c}\text { Agua/Sólido } \\
\text { water/solid } \\
\mathbf{( L / S )}\end{array}$} & \multicolumn{2}{c|}{$\begin{array}{c}\text { Resistencias mecánicas } \\
\text { Mechanical strengths (Mpa) }\end{array}$} \\
\cline { 2 - 3 } & $\mathbf{N a}_{\mathbf{2}} \mathbf{\mathbf { O }} / \mathbf{A l}_{\mathbf{2}} \mathbf{O}_{\mathbf{3}}$ & $\mathbf{S i O}_{\mathbf{2}} / \mathbf{A l}_{\mathbf{2}} \mathbf{O}_{\mathbf{3}}$ & & Flexión & compresión \\
\hline 1 & 1.00 & 3.5 & 0.18 & $22.1 \pm 2.0$ & $88.9 \pm 4.5$ \\
\hline 2 & 1.00 & 4.0 & 0.18 & $19.1 \pm 1.8$ & $102.1 \pm 3.8$ \\
\hline 3 & 1.00 & 4.5 & 0.18 & $10.3 \pm 1.1$ & $49.8 \pm 5.2$ \\
\hline 4 & 0.75 & 3.5 & 0.18 & $10.7 \pm 1.2$ & $60.6 \pm 3.9$ \\
\hline 5 & 0.75 & 4.0 & 0.18 & $17.7 \pm 2.2$ & $81.7 \pm 2.5$ \\
\hline 6 & 0.75 & 4.5 & 0.18 & $6.1 \pm 0.8$ & $45.0 \pm 3.1$ \\
\hline 7 & 0.50 & 3.5 & 0.18 & $6.3 \pm 0.7$ & $50.5 \pm 3.2$ \\
\hline 8 & 0.50 & 4.0 & 0.18 & $5.9 \pm 0.8$ & $64.1 \pm 4.4$ \\
\hline 9 & 0.50 & 4.5 & 0.18 & $2.2 \pm 1.1$ & $25.9 \pm 3.8$ \\
\hline
\end{tabular}

En el presente trabajo se estudiaron nueve composiciones diferentes en las que se modificaron las relaciones $\mathrm{Na}_{2} \mathrm{O} / \mathrm{Al}_{2} \mathrm{O}_{3}$ y $\mathrm{SiO}_{2} / \mathrm{Al}_{2} \mathrm{O}_{3}$ (ver Tabla 2). Para variar la relación $\mathrm{Na}_{2} \mathrm{O} / \mathrm{Al}_{2} \mathrm{O}_{3}$ a la disolución de waterglass se añadió sosa ( $\mathrm{NaOH}$ del $98 \%$ de pureza) en forma de lentejas, en las cantidades adecuadas. Para alcanzar relaciones $\mathrm{SiO}_{2} / \mathrm{Al}_{2} \mathrm{O}_{3}=4,5$ (muestras 3, 6 y 9, ver Tabla 2) además de waterglass se adicionó humo de sílice cuya composición se detalla en la Tabla 1. Los cálculos (en moles) se hicieron sobre la base de las composiciones químicas de los materiales de partida (tanto los sólidos como los líquidos). La relación "Agua/sólido" se mantuvo siempre constante e igual a 0,18 en la totalidad de las composiciones estudiadas ya que en experimentaciones preliminares esta relación se había considerado como óptima

En el curado de las pastas se empleó el método denominado "Curing in covered moulds (CCM)" (24). Este procedimiento, utilizado en investigaciones previas, tiene en cuenta el hecho de mantener las condiciones adecuadas de humedad mientras el material fragua y endure, para prevenir fraguados rápidos (12-14) y/o procesos de carbonatación (27). El ensayo consiste en introducir los moldes, conteniendo la pasta fresca, en bolsas de plástico individuales y selladas con el objeto de impedir la evaporación del agua durante el proceso inicial de curado. Posteriormente las pastas de composición molar
In the present research, the nine compositions studied differed in terms of the $\mathrm{Na}_{2} \mathrm{O} / \mathrm{Al}_{2} \mathrm{O}_{3}$ and $\mathrm{SiO}_{2} / \mathrm{Al}_{2} \mathrm{O}_{3}$ ratios (see Table 2). The $\mathrm{Na}_{2} \mathrm{O} / \mathrm{Al}_{2} \mathrm{O}_{3}$ ratio was varied by adding suitable amounts of caustic soda pellets (98\% pure $\mathrm{NaOH}$ ) to the waterglass. To attain $\mathrm{SiO}_{2} / \mathrm{Al}_{2} \mathrm{O}_{3}$ ratios of 4.5 (samples 3, 6 and 9, see Table 2), silica fume, whose composition is set out in Table 1, was added to the waterglass. The calculations (in moles) were performed based on the chemical compositions of the initial materials (both solids and liquids). The optimal "water/solid" ratio found in preliminary experiments, 0.18 , was used consistently throughout.

The pastes were cured pursuant to the "curing in covered moulds (CCM)" technique (24). Used in previous research, this procedure maintains the appropriate moisture during material setting and hardening to prevent premature setting (12-24) and/or carbonation (27). The trial consisted in placing the moulds with the fresh paste in sealed individual plastic bags to prevent water evaporation during initial curing. Subsequently the pastes whose $\mathrm{SiO}_{2} / \mathrm{Al}_{2} \mathrm{O}_{3}$ ratio was 3.5 or 4.0 were cured for eight hours at $95^{\circ} \mathrm{C}$, while the pastes particularly rich in 
$\mathrm{SiO}_{2} / \mathrm{Al}_{2} \mathrm{O}_{3}=3,5$ y 4,0 fueron curadas durante 8 horas a $95^{\circ} \mathrm{C}$, mientras que las pastas especialmente ricas en sílice (composiciones 3, 6 y 9, ver Tabla 2) fueron curadas durante 24 horas a $60^{\circ} \mathrm{C}$ al objeto de prevenir cualquier fenómeno expansivo en las mismas (12).

Las resistencias mecánicas de los materiales endurecidos fueron determinadas sobre probetas prismáticas de $1 \times 1 \times 6 \mathrm{~cm}, 24$ horas después del proceso de curado térmico. La mineralogía y la microestructura de los productos de reacción fue estudiada por medio de la Difracción de Rayos X y de Espectroscopía Infrarroja. El difractómetro utilizado fue un Philips PW 1730 que utiliza radiación CuK $\alpha$. Las muestras se examinaron en el rango $2 \theta$ comprendido entre $5^{\circ}$ y $60^{\circ}$ con una velocidad de barrido de $2 \%$ min. En cuanto al espectrómetro de radiación infrarroja éste fue un ATI Mattson, FTIR-TM series. Las muestras para el análisis por FTIR se prepararon por el procedimiento del comprimido de $\mathrm{KBr}$. Los análisis se llevaron a cabo en el rango espectral comprendido entre $400 \mathrm{~cm}^{-1} \mathrm{y}$ $1.600 \mathrm{~cm}^{-1}$ con una resolución de $4 \mathrm{~cm}^{-1}$.

El grado de avance de la reacción se determinó por medio de un ataque químico selectivo de los materiales con una disolución de $\mathrm{HCl}$ 1:20 (en volumen) a temperatura ambiente y por un periodo de 3 horas. Este ataque permite disolver los productos de reacción generados en el proceso de activación alcalina de las cenizas volantes (29); es decir, permite separar el material de partida que no ha reaccionado de los productos de reacción formados.

\section{RESULTADOS}

\subsection{Resistencias mecánicas}

Las resistencias mecánicas (flexotracción y compresión) desarrolladas por las probetas prismáticas de ceniza activada, tras el curado térmico en estufa, se detallan en la Tabla 2 y se representan en la Figura 1. Los resultados de la presente investigación ponen de manifiesto que las resistencias mecánicas del material son muy elevadas cuando la ratio molar $\mathrm{SiO}_{2} / \mathrm{Al}_{2} \mathrm{O}_{3}$ es de 3,5 o incluso 4,0 pero estas descienden cuando dicha ratio se sitúa en 4,5. Todo parece indicar que un contenido de sílice muy elevado en el sistema de partida origina un punto de inflexión en el desarrollo mecánico del material.

Cuando se observa la evolución de las resistencias mecánicas con la variación de las ratios $\mathrm{SiO}_{2} / \mathrm{Al}_{2} \mathrm{O}_{3}$ y $\mathrm{Na}_{2} \mathrm{O} / \mathrm{Al}_{2} \mathrm{O}_{3}$ (ver Tabla 2 y Figura 1 ), se deduce también que dichas resistencias aumentan al mismo tiempo que aumenta la alcalinidad del sistema. No obstante, incluso valores no excesivamente altos de la alcalinidad $\left(\mathrm{Na}_{2} \mathrm{O} / \mathrm{Al}_{2} \mathrm{O}_{3}=0,5\right)$ son suficientes para inferir al sistema una notable capacidad reactiva; en este caso se pueden silica (compositions 3, 6 and 9, see Table 2) were cured for 24 hours at $60^{\circ} \mathrm{C}$ to prevent expansion (12).

Prismatic specimens measuring $1 \times 1 \times 6 \mathrm{~cm}$ were prepared to find the 24-hour mechanical strength of the hardened materials. Reaction product mineralogy and microstructure were studied with $X$-ray diffraction and infrared spectroscopy techniques. Samples were scanned in the $5^{\circ}$ to $60^{\circ} 2 \theta$ range at a rate of $2 \%$ min on a Philips PW 1730 (CuK $\alpha$ radiation) diffractometer. Compressed $\mathrm{KBr}$ pellets were prepared for analysis on an ATI Mattson FTIR-TM series infrared radiation spectrometer. The spectral range was 400 to $1,600 \mathrm{~cm}^{-1}$ and the resolution $4 \mathrm{~cm}^{-1}$.

Reaction progress was determined by a selective, 3-hour chemical attack on the materials with a 1:20 (by volume) solution of $\mathrm{HCl}$ at ambient temperature. This method dissolves the reaction products generated during the alkali activation of fly ash (29); i.e., it separates the unreacted initial material from the reaction products formed.

\section{RESULTS}

\subsection{Mechanical strength}

The flexural and compressive strength developed by the activated ash prismatic specimens, after thermal curing in an oven, are given in Table 2 and plotted in Figure 1. The results of the present study show that material strength was very high when the $\mathrm{SiO}_{2} / \mathrm{Al}_{2} \mathrm{O}_{3}$ molar ratio was 3.5 or even 4.0, but that it declined when the ratio was 4.5. The inference is that a high silica content in the initial system originates an inflection point in mechanical strength development.

Mechanical strength was also observed to rise with system alkalinity, as the values for different $\mathrm{SiO}_{2} / \mathrm{Al}_{2} \mathrm{O}_{3}$ and $\mathrm{Na}_{2} \mathrm{O} / \mathrm{Al}_{2} \mathrm{O}_{3}$ ratios show (see Table 2 and Figure 1). Nonetheless, even alkalinity levels that were not exceedingly high $\left(\mathrm{Na}_{2} \mathrm{O} / \mathrm{Al}_{2} \mathrm{O}_{3}=0,5\right)$ sufficed to confer subs- 
alcanzar hasta $64 \mathrm{MPa}$ de resistencia a la compresión en un corto periodo de tiempo.

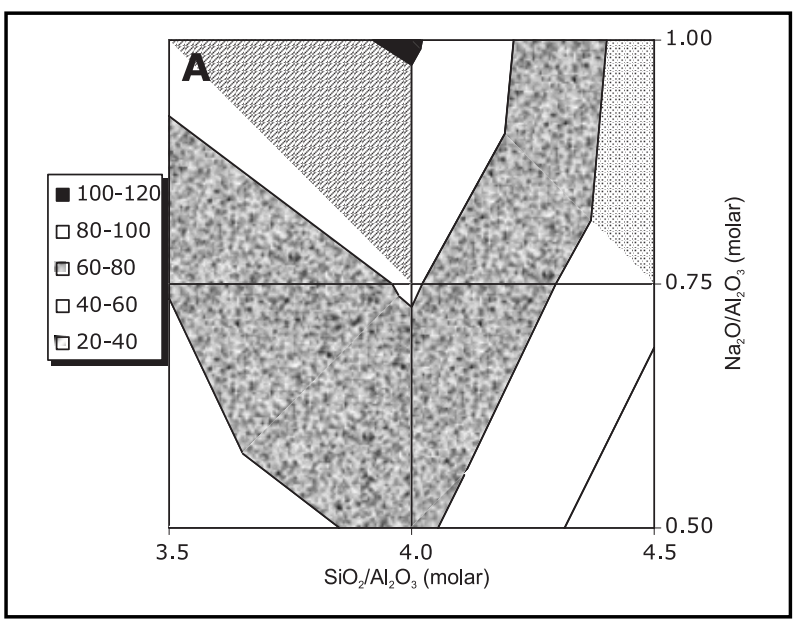

tantial reactivity on the system and attain compressive strength values of $64 \mathrm{MPa}$ in short periods of time.

Figura 1. Evolución de las resistencias mecánicas a compresión (a) y a flexotracción (b) en MPa para la ceniza activada alcalinamente en función de la relación molar $\mathrm{Na}_{2} \mathrm{O} / \mathrm{Al}_{2} \mathrm{O}_{3}$ y $\mathrm{SiO}_{2} / \mathrm{Al}_{2} \mathrm{O}_{3}$.

Figure 1. Compressive (a) and bending (b) strength in MPa for alkali-activated ash vs $\mathrm{Na}_{2} \mathrm{O} / \mathrm{Al}_{2} \mathrm{O}_{3}$ and $\mathrm{SiO}_{2} / \mathrm{Al}_{2} \mathrm{O}_{3}$ molar ratios.

\subsection{Difracción de rayos- $X$}

Al analizar los datos representados en la Figura 2 (difractogramas de rayos $X$ de los materiales de trabajo) se pueden deducir con facilidad algunas características comunes, y también algunas diferencias, en torno a la mineralogía de los sistemas objeto de estudio: la activación alcalina de la ceniza original afecta sobre todo a la fase vítrea de la ceniza y en menor medida a las fases cristalinas que forman parte de dicha ceniza (17). Este hecho se observa en todos los difractogramas de la Figura 2. Por un lado las señales correspondientes al cuarzo, mullita y magnetita (fases todas ellas pertenecientes a la ceniza de parti$\mathrm{da})$, permanecen aparentemente inalteradas como consecuencia de la activación alcalina $(30,31)$; es decir, los picos de difracción que las caracterizan aparecen siempre en los mismos ángulos y con las mismas intensidades. Sin embargo, el halo característico de los compuestos amorfos o vítreos que en la ceniza de partida aparece aproximadamente entre $2 \theta=20$ y $2 \theta=30$, se desplaza visiblemente en el resto de difractogramas de la Figura 2, hacia posiciones comprendidas entre $2 \theta=25$ y $2 \theta=35$. Este desplazamiento indica una reorganización estructural del componente vítreo del material de partida como consecuencia del ataque alcalino. Dicha reestructuración [no interpretable con los datos que aporta la Difracción de rayos $\mathrm{X}$ pero hoy día comprendida gracias a la información facilitada por otras técnicas instrumentales (FTIR y 29Si NMR especialmente) $(15,18,32)]$ implica la inicial disolución en el medio alcalino del vidrio que forma parte de la ceniza y la posterior precipitación del material

\subsection{X-ray difracction}

An analysis of the data shown in Figure 2 (X-ray diffractograms of the working materials) reveals both the common characteristics and the differences in the mineralogy of the systems studied: alkali activation primarily affected the vitreous phase of the original ash, and its crystalline phases only scantly (17). This can be seen in all the XRD patterns in Figure 2. The signals for quartz, mullite and magnetite (all found in the initial ash) remained apparently unaltered after alkali activation $(30,31)$; in other words, their characteristic diffraction peaks always appeared at the same angles and with the same intensities. The characteristic halo corresponding to the amorphous or vitreous compounds, however, which in the initial ash appeared at approximately between $2 \theta=20$ and $2 \theta=30$, shifted visibly in the remaining diffractograms in Figure 2 to positions between $2 \theta=25$ and $2 \theta=35$. Such shifts denote structural reorganization of the vitreous component in the initial material as a result of the alkaline attack. While such restructuring cannot be interpreted with the data furnished by X-ray diffraction alone, today it is understood thanks to the information provided by other instrumental techniques (FTIR and 29 Si NMR in particular) $(15,18,32)$. It involves the initial dissolution of the glassy component of the ash in the alkaline medium and subsequent precipitation of the dissolved material in the form of an aluminosilicate-type gel, sometimes like- 
disuelto en forma de un gel de naturaleza aluminosilicica, con estructura tridimensional, que ya ha sido definido en ocasiones previas como un "precursor zeolitico" $(5,15)$. ned to a "zeolite precursor" on the grounds of the nature of its three-dimensional structure $(5,15)$.
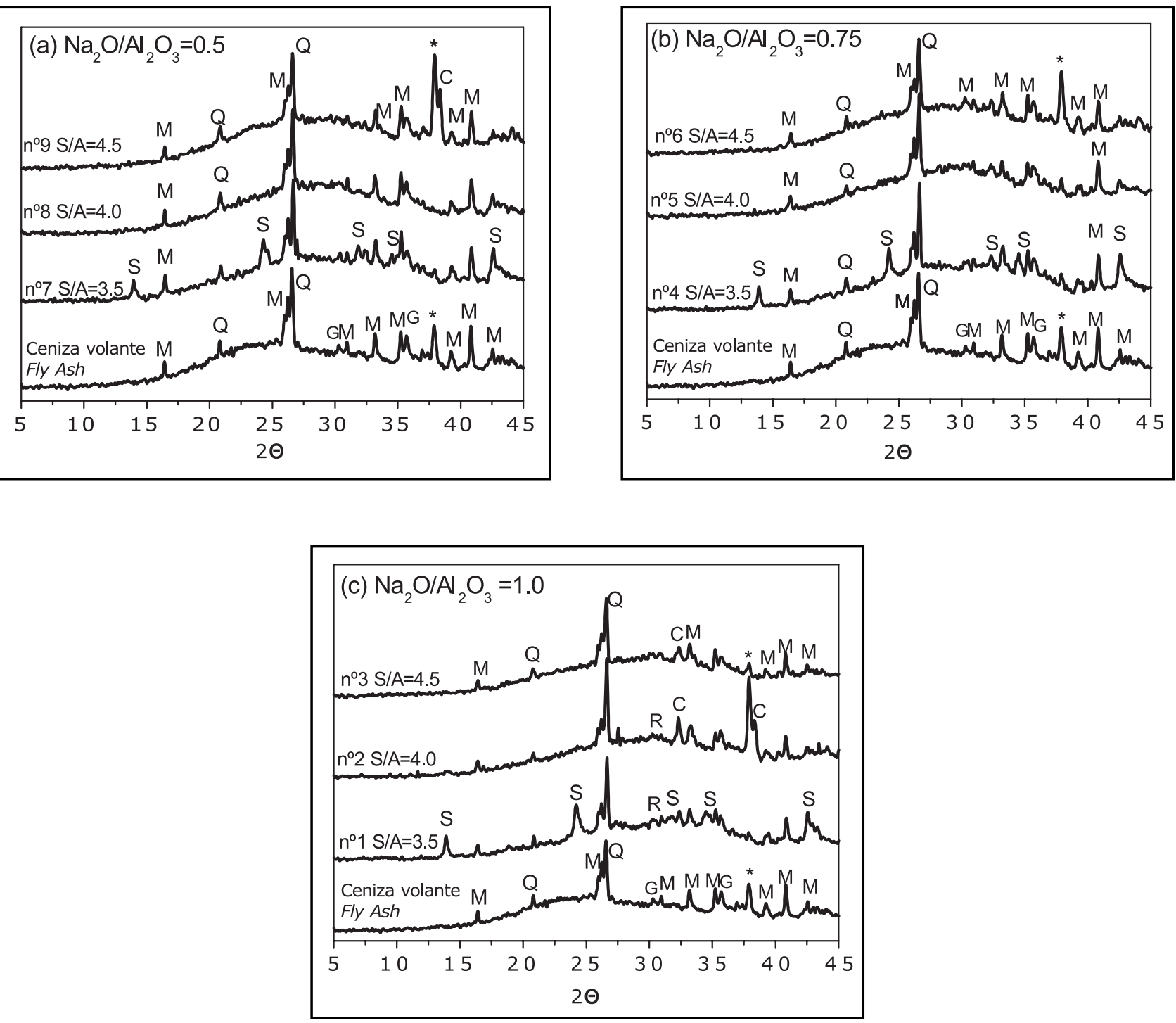

Figura 2. Espectros de DRX de la ceniza original y de los materiales activados; (a) relación N/A=0,5; (b) relación N/A=0.75;

(c) relación N/A=1.0 (leyenda Q- Quartz; M- Mullite; G- magnetite; S - Hydroxysodalite;

$\mathrm{C}-\mathrm{NaHCO}_{3} ; \mathrm{R}$ - Na-chabazite; * Instrumental artefact.

Figure 2. XRD patterns for the original ash and activated materials: (a) N/A ratio $=0.5 ;$ (b) N/A ratio $=0.75 ;(c)$ N/A ratio $=1.0$ (legend: Q-quartz, M-mullite; G-magnetite; S-Hydroxysodalite; $\mathrm{C}-\mathrm{NaHCO}_{3} ; \mathrm{R}$ - chabazite-Na; * instrumental artefact.

En segundo lugar, se ha de enfatizar el hecho de que en la totalidad de los materiales preparados apenas cristalizan zeolitas como productos secundarios del proceso de activación alcalina, a pesar de que el crecimiento de cristales zeoliticos es relativamente habitual en los sistemas cementantes basados en la activación alcalina de cenizas volantes $(17,29)$. Esta observación concuerda plenamente con trabajos previos en los que ya se destacó la dificultad cinética de las zeolitas para cristalizar en sistemas
Furthermore, zeolites barely crystallized as secondary products of alkali activation in any of the materials prepared, even though the growth of zeolite crystals is fairly common in cementitious systems based on the alkali activation of fly ash $(17,29)$. This observation concurs fully with prior studies that drew attention to the kinetic obstacles to zeolite crystallization in systems with a high silica content (32-34), for in order to generate crystalline zeolites, such systems call for very intense curing condi- 
con elevados contenidos de sílice (32-34); ya que este tipo de sistemas necesita, para generar zeolitas cristalinas, de condiciones de curado muy intensas (largos tiempos y/o altas temperaturas), tecnológicamente no aplicables en sistemas cementantes.

Así, en general, en los difractogramas de la Figura 2 sólo se detectan (como fases secundarias de reacción) dos tipos de zeolitas: Hidroxisodalita y Na-Chabazita. También se puede observar, en algunas ocasiones, la presencia de Carbonato Sódico

La Hidroxisodalita (JCPDF 42-0216) es una zeolita de características especiales; algunos autores consideren que no debería ser clasificada como tal zeolita. Su estabilidad termodinámica es tal que cuando se dan las condiciones de alcalinidad suficientes, su cristalización es relativamente rápida y sencilla $(35,36)$. En el caso concreto de esta investigación, la Hidroxisodalita se detecta fundamentalmente en los sistemas menos ricos en sílice $\left(\mathrm{SiO}_{2} / \mathrm{Al}_{2} \mathrm{O}_{3}=3,5\right)$ dado que al igual que ocurre con todas las zeolitas su cinética de formación es lenta en sistemas con elevados contenidos de sílice. En este sentido, hay que destacar la casi constante intensidad de las señales de difracción de la Hidroxisodalita en la totalidad de los difractogramas de la Figura 2 para las muestras 1,4 y 7 (misma relación S/A pero diferente alcalinidad). Este hecho podría estar indicando, o bien que las condiciones concretas de formación de la Hidroxisodalita no están excesivamente supeditadas a la alta alcalinidad del medio o que en el tipo de sistemas con los que se ha llevado a cabo esta investigación es posible encontrar heterogeneidades locales que permiten la precipitación de dicha zeolita.

En algunos de los difractogramas (los que corresponden a la máxima alcalinidad de cada composición: $\mathrm{Na}_{2} \mathrm{O} / \mathrm{Al}_{2} \mathrm{O}_{3}$ $=1$, muestras 1,2 y 3 ), se observa la existencia de un pequeño pico de difracción en $d=0,295$, parcialmente solapado con una señal del cuarzo, que podría deberse a la presencia en dichos sistemas de pequeñas cantidades de Na-Chabazita o Herschelita (JCPDF 19-1178). La cristalización de esta zeolita ha sido observada muy frecuentemente, por diversos autores, en sistemas con relaciones $\mathrm{SiO}_{2} / \mathrm{Al}_{2} \mathrm{O}_{3}$ comprendidas entre 1 y 2 (35-37), pero también en sistemas análogos a los aquí estudiados, es decir en condiciones de elevados contenidos de sílice $(23,37)$.

Finalmente, a través de la Difracción de rayos $X$ se identificó en algunas de las composiciones de trabajo, la presencia de carbonato sódico. La formación de dicho compuesto tiene lugar durante el proceso de curado, si las condiciones de humedad no son las más idóneas (24, 27), como consecuencia de la reacción de carbonatación que se da entre el álcali del medio que aun no ha reac- tions (long time and/or high temperature) that are not technologically applicable to cementitous systems.

In general, then, only two types of zeolites (as secondary reaction phases) were detected on the patterns in Figure 2: hydroxysodalite and chabazite-Na. Sodium carbonate was also present on occasion.

Hydroxysodalite (JCPDF 42-0216) is a zeolite with special characteristics that some authors believe should not be classified as a zeolite at all. In a sufficiently alkaline medium, it is so thermodynamically stable that it crystallizes fairly quickly and easily $(35,36)$. In this specific study, hydroxysodalite was found essentially in the less silica-rich systems $\left(\mathrm{SiO}_{2} / \mathrm{Al}_{2} \mathrm{O}_{3}=3.5\right)$, since as in the case of all zeolites, its formation kinetics are slow in systems with a high silica content. Note in this regard that the intensity of the hydroxysodalite diffraction signal was nearly constant in the patterns in Figure 2 for samples 1 , 4 and 7 (same S/A ratio but different alkalinity). This finding may mean either that the specific conditions for hydroxysodalite formation are not especially affected by the high alkalinity of the medium or that local heterogeneities that would favour its precipitation may be found in the type of systems in which the study was conducted.

Some of the diffractograms (the ones with the highest alkalinity in each composition: $\mathrm{Na}_{2} \mathrm{O} / \mathrm{Al}_{2} \mathrm{O}_{3}=1$, samples 1,2 and 3) showed a small diffraction peak at $d=0.295$, partially overlapping with a quartz signal, which may be due to the presence in these systems of small amounts of chabazite-Na or herschelite (JCPDF 19-1178). This zeolite has been observed to crystallize in systems with $\mathrm{SiO}_{2} / \mathrm{Al}_{2} \mathrm{O}_{3}$ ratios of from 1 to 2 by different authors (35$37)$, but also in systems similar to the ones studied here, i.e., with a high silica content $(23,37)$.

Finally, X-ray diffraction also identified sodium carbonate in some of the working compositions. If moisture conditions are not ideal, this compound forms in the curing phase as a result of the carbonation reaction between atmospheric $\mathrm{CO}_{2}$ and the unreacted alkali in the medium $(24,27)$. In the systems studied, the most highly carbonated compositions were the ones with the highest alka- 
cionado con la ceniza y el $\mathrm{CO}_{2}$ atmosférico. En los sistemas objeto de estudio todo parece indicar que las composiciones que mayor carbonatación han sufrido son precisamente aquellas más ricas en álcalis; aquéllas con $\mathrm{Na}_{2} \mathrm{O} / \mathrm{Al}_{2} \mathrm{O}_{3}=1$ (muestras 1,2 y 3). La presencia de cantidades abundantes de carbonato sódico puede ser muy perjudicial para el desarrollo de las reacciones de activación de la ceniza dado que dicho compuesto acidifica el medio de forma significativa, y por lo tanto, neutraliza aquellas condiciones óptimas (de elevada alcalinidad) en las que se ha de producir la formación del gel de aluminosilicato sódico.

\subsection{Espectroscopía IR por transformada de Fourier}

En la interpretación de los espectros de IR de la Figura 3 hay una serie de consideraciones previas que entendemos es importante señalar. En primer lugar que la asignación de las bandas se ha hecho tomando en consideración los patrones habitualmente aceptados en el estudio de los silicatos, en general, y en el campo de las zeolitas en particular (11-13, 37-39), y en segundo lugar que la estructura de los silicatos y aluminosilicatos, en general, está constituida por unidades cíclicas que se forman por la conexión de tetraedros de aluminio y silicio a través de puentes de oxígeno, con diferente número de miembros.

El espectro de la ceniza original (ver Fig. 3) muestra tres bandas anchas características de las vibraciones internas de los silicatos $(30,38)$. La banda que aparece a 1.060 $\mathrm{cm}^{-1}$ se asocia a las vibraciones de tensión asimétricas de los enlaces T-O ( $\mathrm{T}=\mathrm{Si}$ ó Al), (banda 1, Figura 3); la banda que aparece hacia $457 \mathrm{~cm}^{-1}$ (banda 7, Figura 3) se asocia a las vibraciones de deformación de los enlaces $\mathrm{Si}-\mathrm{O}-\mathrm{Si}$, cuya intensidad es independiente del grado de cristalinidad del material. La banda que aparece hacia 780-790 $\mathrm{cm}^{-1}$, se corresponde con las vibraciones $v_{5}$ (Si-O-Si) del doblete característico del cuarzo presente en la ceniza original. Por último, la banda de $547 \mathrm{~cm}^{-1}$ (banda 6, Figura 3) se corresponde con las vibraciones del aluminio octaédrico presente en la mullita (38).

En los espectros de las Figuras 3(a), (b) y (c) se puede observar el efecto que ejerce el medio altamente alcalino sobre la ceniza de partida: gran parte de la fase vítrea de la ceniza se disuelve en dicho medio para precipitar posteriormente en forma de gel aluminosilicico. Este hecho se deduce del desplazamiento que se observa en la banda de vibración de los enlaces T-O en la zona de frecuencias comprendida entre 990 y $1.070 \mathrm{~cm}^{-1}$ (banda 1, Figura 3). Dicho desplazamiento es diferente para cada una de las composiciones objeto de estudio lo cual es indicativo de que los productos de reacción poseen, en cada caso, diferentes esqueletos estructurales, al menos en lo que respecta a la ratio $\mathrm{Si} / \mathrm{Al}$. li content, i.e., with $\mathrm{Na}_{2} \mathrm{O} / \mathrm{Al}_{2} \mathrm{O}_{3}=1$ (samples 1, 2 and 3). The presence of large amounts of sodium carbonate may be very detrimental to the development of ash activation reactions because it acidifies the medium significantly, neutralizing the optimum conditions (high alkalinity) for the formation of sodium aluminosilicate gel.

\subsection{Fourier transform infrared spectroscopy}

A number of remarks are in order prior to interpreting the IR spectra in Figure 3. Firstly, the bands were allocated on the basis of the widely accepted patterns for the study of silicates in general and zeolites in particular (11-13, 37-39); and secondly, as a general rule silicates and aluminosilicates are structured around cyclic units formed by the connection of aluminium and silicon tetrahedra across oxygen bridges, with a variable number of members.

The IR spectrum for the original ash (see Figure 3) contained two wide bands characteristic of the internal vibrations in the silicate $(30,38)$. The band appearing at $1,060 \mathrm{~cm}^{-1}$ was attributed to $T-O(T=A l, S i)$ bond asymmetric stretching vibrations (band 1, Figure 3), while the band at $457 \mathrm{~cm}^{-1}$ (band 7, Figure 3) was associated with $\mathrm{Si}-\mathrm{O}-\mathrm{Si}$ bond bending vibrations, whose intensity was independent of the degree of crystallinity prevailing in the material. The band appearing at 780$790 \mathrm{~cm}^{-1}$ corresponded to the $v^{5}$ (Si-O-Si) vibrations that generate the double band characteristic of the quartz present in the initial ash. Lastly, the band at $547 \mathrm{~cm}^{-1}$ (band 6, Figure 3) was assigned to the octahedral aluminium present in the mullite (38).

The effect of a highly alkaline medium on the initial ash can be observed in the spectra in Figures 3(a), (b) and (c): most of the vitreous phase of the ash dissolved in that medium and subsequently precipitated in the form of an aluminosilicate-like gel. This can be deduced from the shift observed in the T-O bond vibration band across frequencies from 990 to $1070 \mathrm{~cm}^{-1}$ (band 1, Figure 3). This shift varied from one composition to another, indicating that the reaction products had different structural skeletons in each case, at least as far as their Si/Al ratio was concerned. 

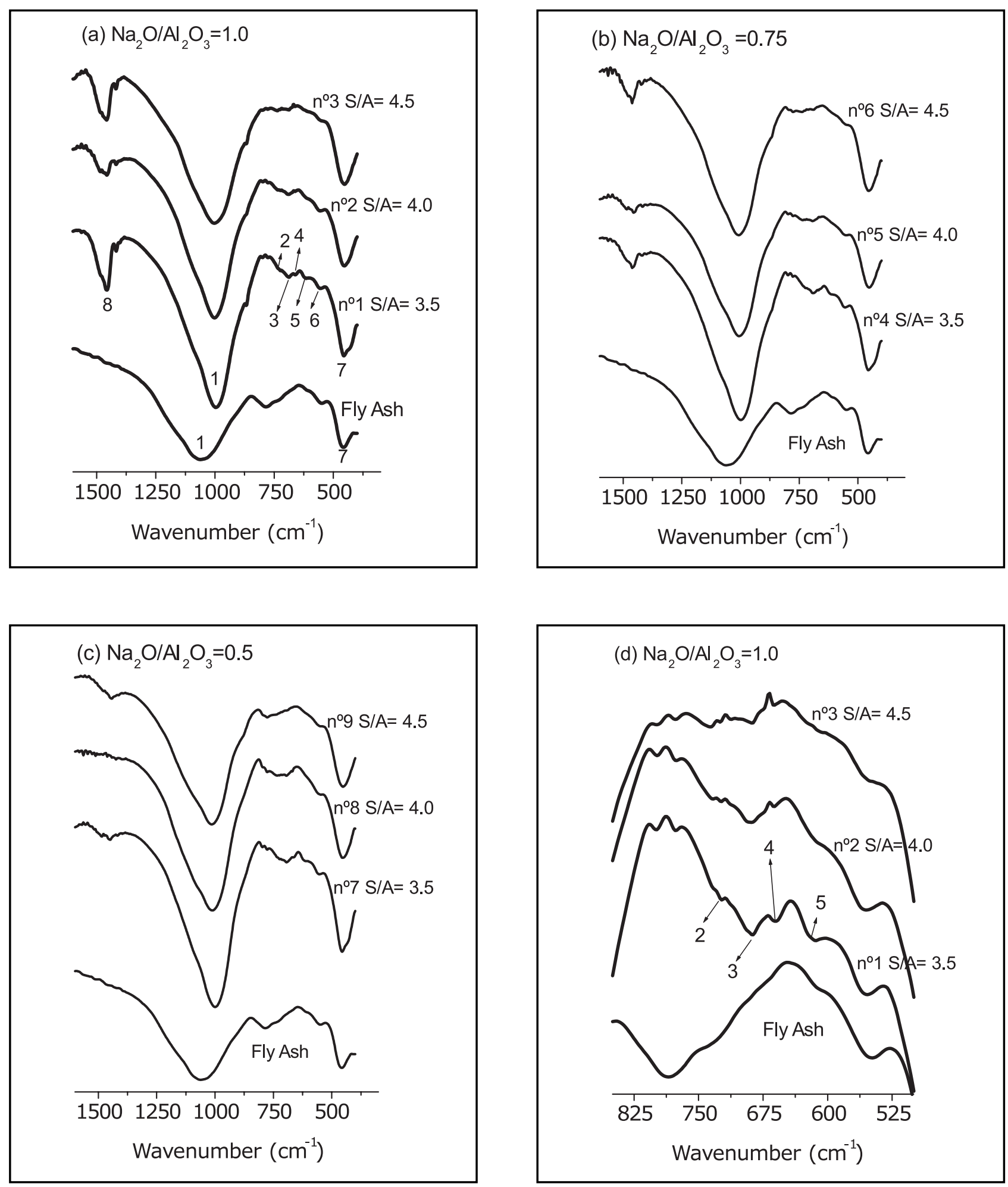

Figura 3 .Espectros de FTIR de la ceniza original y de los materiales activados; (a) relación N/A=1.0; (b) relación N/A=0.75; (c) relación N/A=0.5; (d) ampliación de la zona entre $800-500 \mathrm{~cm}^{-1}$ de la Figura $3(\mathrm{a})$.

Figure 3. FTIR spectra of the original ash and activated materials: (a) N/A ratio=1.0; (b) N/A ratio=0.75; (c) $N / A$ ratio $=0.5 ;(d)$ enlargement of the $800-500 \mathrm{~cm}^{-1}$ range in Figure $3(a)$.

En cuanto a las bandas que aparecen entre $800-500 \mathrm{~cm}^{-1}$ (bandas 2, 3, 4 y 5, ver Fig.3) se asocian a las vibraciones de los tetraedros que forman la denominada
The bands appearing between 800 and $500 \mathrm{~cm}^{-1}$ (bands 2, 3, 4 and 5, see Figure 3) were associated with fragments of the aluminosilicate network and vibrations in 
Secondary Building Units (SBU) y a fragmentos de la red de aluminosilicatos. De acuerdo con la bibliografía (37-39) estas bandas se asocian con la presencia de anillos de diferente numero de unidades, que, a su vez, pueden unirse para formar estructuras tridimiensionales. Así, un incremento en el número de miembros del anillo causa un desplazamiento de las bandas hacia frecuencias menores. También, el número de tetraedros de $\left[\mathrm{AlO}_{4}\right]^{5-}$ presentes en el anillo es origen de modificaciones en la geometría del anillo y consecuentemente en la posición de las bandas del espectro. Cuando se comparan anillos con el mismo número de miembros pero diferente número de tetraedros de $\mathrm{AlO}_{4}$, en general se observa que el aumento del número de tetraedros de $\mathrm{AlO}_{4}$, implica una disminución del grado de deformación del anillo. Estos resultados encuentran su ultima explicación en la diferente naturaleza de los enlaces Al-O y Si-O (diferentes energías de enlace, así como diferentes radios iónicos de $\mathrm{Al}^{3+}$ y $\mathrm{Si}^{4+}$ ).

Concretamente las bandas que aparecen entre 720-650 $\mathrm{cm}^{-1}$ (bandas 2, 3, y 4 Fig. 3(d)) según la teoría de los aluminosilicatos, puede asociarse a vibraciones de los enlaces T-O de los tetraedros unidos formando anillos de 4 eslabones (S4R) bien en estructuras tipo hidroxisodalita (37-39) (fase identificada por DRX) o bien debidas a vibraciones de anillos de 4 eslabones observados en minerales del grupo D6R (ie. Chabazite $\mathrm{Si} / \mathrm{Al}=2$ ). La banda que aparece entre $650 \mathrm{~cm}^{-1}$ and $500 \mathrm{~cm}^{-1}$ es característica de estructuras del tipo D6R (37-39), y, por lo tanto, asignable a la Chabazita (mineral detectado por DRX). Como es de prever las muestras que presentan una menor relación $\mathrm{SiO}_{2} / \mathrm{Al}_{2} \mathrm{O}_{3}$ (muestras 1,4 y 7 ) al tener un mayor grado de zeolitizacion son las que dan lugar a bandas más intensas en esta zona del espectro.

Por otra parte, los espectros FTIR de la Figura 3 también aportan alguna información en torno a los niveles de carbonatación de los materiales objeto de estudio (banda 8). La intensidad de la banda que aparece en algunos de dichos espectros en la región entre $1.425-1.450 \mathrm{~cm}^{-1}$ nos indica (coincidiendo con los resultados aportados por la DRX) que los procesos de carbonatación se desarrollan con mayor intensidad en aquellos sistemas de trabajo que poseen una mayor ratio $\mathrm{Na}_{2} \mathrm{O} / \mathrm{Al}_{2} \mathrm{O}_{3}$ (muestras 1 , 2 y 3); es decir, allí donde existe una mayor alcalinidad. Tampoco la espectroscopía IR clarifica la relación existente (si es que la hubiera) entre la carbonatación y la ratio $\mathrm{SiO}_{2} / \mathrm{Al}_{2} \mathrm{O}_{3}$ de los materiales de trabajo. Por otro lado no parece que la variación de la relación $\mathrm{SiO}_{2} / \mathrm{Al}_{2} \mathrm{O}_{3}$ afecte significativamente al grado de carbonatacion de las muestras.

\subsection{Grado de reacción}

El análisis de los grados de reacción se llevó a cabo sobre un número representativo de composiciones (ver Tabla tetrahedra forming so-called Secondary Building Units (SBU). According to the literature $(37,39)$, these bands are associated with the presence of rings with a variable number of units, which may in turn be interconnected to form three-dimensional structures. An increase in the number of members of a ring causes the bands to shift to lower frequencies. The number of $\left[\mathrm{AlO}_{4}\right]^{5-}$ tetrahedra present in the ring also generates changes in ring geometry and consequently in the position of bands on the spectrum. In rings with the same number of members but differing numbers of $\mathrm{AlO}_{4}$ tetrahedra, the presence of more of $\mathrm{AlO}_{4}$ is generally observed to be associated with lesser ring bending. The ultimate explanation for these results is to be found in the different nature of the Al-O and Si-O bonds (different bond energies, as well as different $\mathrm{A}^{\beta+}$ and $\mathrm{Si}^{4+}$ ion radii).

According to the literature on aluminosilicate theory, the bands appearing at around $720-650 \mathrm{~cm}^{-1}$ (bands 2, 3 and 4, Figure $3(d))$, can be attributed to $T-O$ bond vibrations in tetrahedra forming single four rings (S4R) either in hydroxysodalite-type structures (37-39) (phase identified by XRD) or due to the four ring vibrations observed in $D 6 R$ unit minerals (such as chabazite, $S i / A l=2$ ). The bands appearing at $650 \mathrm{~cm}^{-1}$ and $500 \mathrm{~cm}^{-1}$, characteristic of D6R-type structures (37-39), were therefore assignable to chabazite (mineral detected with XRD). As might be expected, the samples with a lower $\mathrm{SiO}_{2} / \mathrm{Al}_{2} \mathrm{O}_{3}$ ratio (samples 1, 4 and 7) gave rise to the most intense bands in this area of the spectrum, due to their higher degree of zeolitization.

Moreover, the FTIR spectra in Figure 3 also furnished information on the carbonation levels in the materials studied (band 8). The intensity of the band appearing on some of these spectra in the $1,425-1,450 \mathrm{~cm}^{-1}$ region signified (concurring with the XRD results) that carbonation was more intense in the working systems with a higher $\mathrm{Na}_{2} \mathrm{O} / \mathrm{Al}_{2} \mathrm{O}_{3}$ ratio (samples 1, 2 and 3), i.e., where alkalinity was higher. The IR spectra failed to clarify the relationship (if one exists) between carbonation and the $\mathrm{SiO}_{2} / \mathrm{Al}_{2} \mathrm{O}_{3}$ ratio in the working materials. In any event, variations in the $\mathrm{SiO}_{2} / \mathrm{Al}_{2} \mathrm{O}_{3}$ ratio did not appear to significantly affect sample carbonation.

\subsection{Degree of reaction}

Degree of reaction was analyzed in a representative number of compositions (see Table 2). The results obtained 
2). Los resultados obtenidos se muestran en la Figura 4 en forma de porcentaje de material soluble en la disolución selectiva de ácido clorhídrico. En dicha Figura se puede observar cómo para una alcalinidad constante (Figura $4(a)$ relación $\mathrm{N} / \mathrm{A}=1.0$ ) la variación de la ratio $\mathrm{SiO}_{2} / \mathrm{Al}_{2} \mathrm{O}_{3}$ no parece modificar sustancialmente al grado de avance de la reacción. El grado de reacción se mantiene casi constante (en torno al 55\%) cuando la ratio $\mathrm{SiO}_{2} / \mathrm{Al}_{2} \mathrm{O}_{3}$ varía entre 3,5 y 4,0 y desciende cuando éste aumenta hasta 4,5 . are shown in Figure 4 as the percentage of soluble material after selective hydrochloric acid dissolution. The figure shows that, when alkalinity was kept constant (Figure $4(a), \mathrm{N} / \mathrm{A}$ ratio $=1.0)$, varying the $\mathrm{SiO}_{2} / \mathrm{Al}_{2} \mathrm{O}_{3}$ ratio did not appear to substantially modify reaction progress. The degree of reaction remained nearly constant (around $55 \%$ ) when the $\mathrm{SiO}_{2} / \mathrm{Al}_{2} \mathrm{O}_{3}$ ratio varied from 3.5 to 4.0 and declined when the ratio climbed to 4.5.
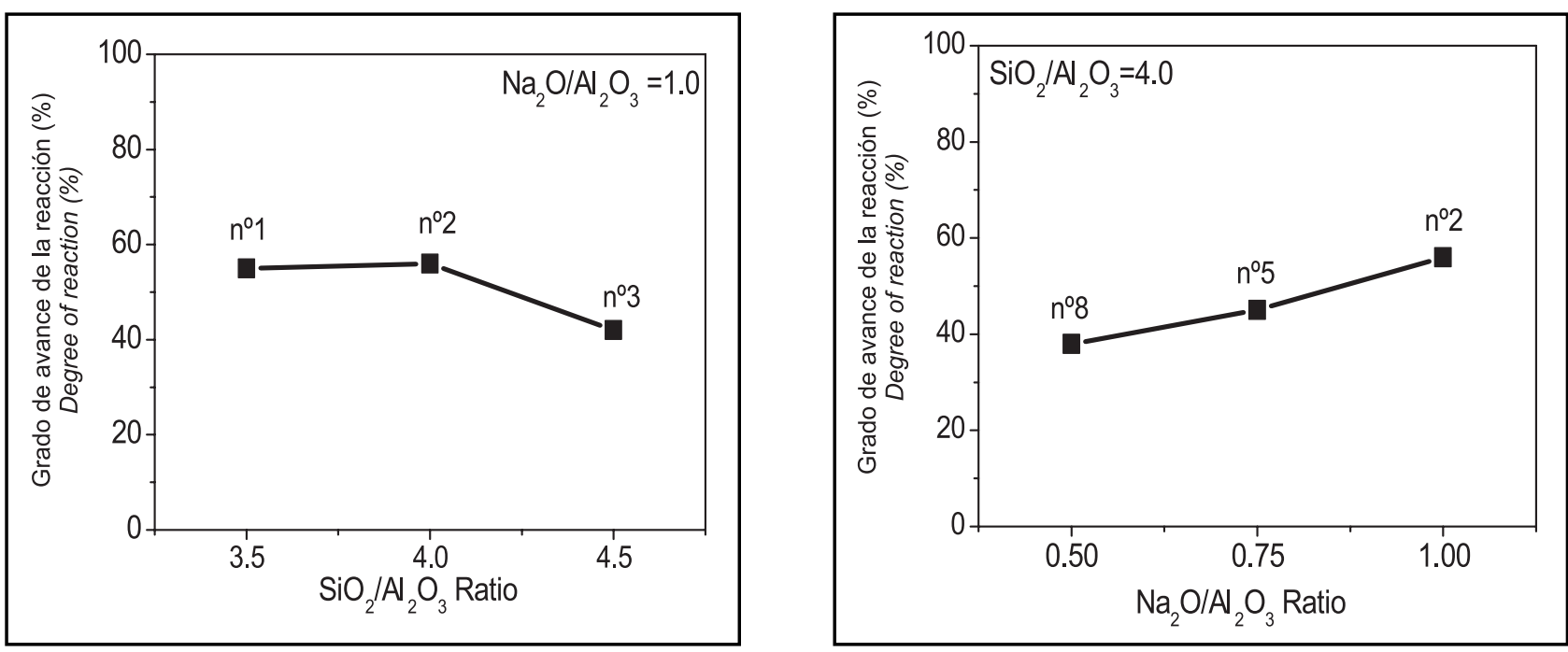

Figura 4 .Grado de avance de la reacción (a) en función del ratio $\mathrm{SiO}_{2} / \mathrm{Al}_{2} \mathrm{O}_{3} ;$ (b) en función del ratio $\mathrm{Na}_{2} \mathrm{O} / \mathrm{Al}_{2} \mathrm{O}_{3}$

Figure 4. Degree of reaction (a) versus $\mathrm{SiO}_{2} / \mathrm{Al}_{2} \mathrm{O}_{3}$ ratio; (b) versus $\mathrm{Na}_{2} \mathrm{O} / \mathrm{Al}_{2} \mathrm{O}_{3}$ ratio.

En la Figura 4(b) se observa que para una relación $\mathrm{SiO}_{2} / \mathrm{Al}_{2} \mathrm{O}_{3}$ constante el aumento de la alcalinidad del medio favorece el incremento del grado de avance de la reacción. Así para un valor de $\mathrm{Na}_{2} \mathrm{O} / \mathrm{Al}_{2} \mathrm{O}_{3}=0,5$ se obtiene un grado de reacción del $38 \%$; cuando la alcalinidad aumenta hasta 1 este valor aumenta hasta un $55 \%$.

\section{DISCUSION}

Confirmando resultados previos de investigaciones realizadas en los últimos años (12-15, 29-33, 37,38), la totalidad de las composiciones descritas en el presente trabajo desarrollan, por medio de la activación alcalina, un gel de silicoaluminato sódico, un precursor zeolitico, que contiene silicios y aluminios tetraédricos distribuidos al azar a lo largo de cadenas poliméricas que están entrecruzadas entre sí y que proporcionan unas cavidades adecuadas para acomodar a los cationes alcalinos y compensar así el déficit de carga que se genera al producirse la sustitución de Si (IV) por Al (III).
Figure 4(b) shows that when the $\mathrm{SiO}_{2} / \mathrm{Al}_{2} \mathrm{O}_{3}$ ratio was constant, increasing the medium alkalinity favoured reaction progress. For a $\mathrm{Na}_{2} \mathrm{O} / \mathrm{Al}_{2} \mathrm{O}_{3}$ value of 0.5 , the degree of reaction was $38 \%$, and climbed to $55 \%$ when alkalinity was raised to a value of 1 .

\section{DISCUSSION}

Confirming the findings of research conducted in recent years (12-15, 29-33, 37, 38), when alkali-activated, all the compositions described in the present paper developed a sodium silicoaluminate gel, a zeolite precursor, with tetrahedral silicon and aluminium atoms distributed at random along intertwined polymerized chains. The cavities formed in these chains accommodated alkaline cations, thereby offsetting the charge deficit generated by the replacement of Si (IV) atoms with Al (III) atoms. 
Mediante datos obtenidos por RMN y FTIR se ha confirmado que en ausencia de sílice soluble, a medida que se incrementa el tiempo de reacción, el gel, inicialmente formado en medios fuertemente alcalinos, metaestable y rico en aluminio (GEL 1 ), evoluciona a una fase más estable y rica en silicio (GEL 2) (32); fase que presenta una estructura tridimensional donde el silicio ocupa diferentes espacios, con predominio de las unidades $\mathrm{Q}^{4}(3 \mathrm{Al})$ y $\mathrm{Q}^{4}(2 \mathrm{Al})$.

La presencia de sílice soluble en el proceso de activación (generalmente en forma de silicato sódico) juega un importante papel en el desarrollo de la microestructura de estos cementos. Un aporte de sílice soluble implica desarrollos microestructurales similares a los que se dan en muchos tipos de vidrio: matriz uniforme y compacta con un escaso contenido de poros (40). Además, el incremento de sílice soluble en el sistema de partida induce a un incremento en el contenido de $\mathrm{Si}$ y $\mathrm{Na}$ de la estructura de estos cementos $(41,42)$, lo que no parece que afecte en gran medida a los mecanismos que gobiernan las reacciones pero que definitivamente afecta a la química de las fases involucradas en las reacciones, a las cinéticas de dichas reacciones $y$, por supuesto, a las propiedades del producto final.

En el caso concreto de la investigación aquí descrita, el objetivo fundamental que se perseguía era el de correlacionar las resistencias mecánicas desarrolladas por una ceniza volante activada alcalinamente, con las modificaciones composicionales inferidas al sistema de partida por la adición de diferentes cantidades de álcalis en forma de hidróxido sódico y de diferentes cantidades de sílice soluble básicamente en forma de silicato sódico. De la misma manera, también era objetivo inicial de esta investigación interpretar dichas correlaciones en términos de diferencias mineralógicas y microestructurales entre los distintos materiales sintetizados.

En la Figura 5, se observa la correlación existente entre la microestructura que desarrolla el material (determinada por la posición de la banda de vibración de enlaces TO) y la composición de los diferentes materiales estudiados. Así, para ratios $\mathrm{SiO}_{2} / \mathrm{Al}_{2} \mathrm{O}_{3}$ constantes, se observa que a medida que disminuye la alcalinidad del sistema la banda de tensión de los enlaces T-O aparece a frecuencias mayores. Este comportamiento en un principio podría interpretarse como debido a la formación de geles con una mayor relación Si/Al (37). Si esta suposición fuese correcta, al disminuir la alcalinidad las resistencia mecánicas deberían aumentar ya que los enlaces Si-O-Si son más fuertes que los enlaces Si-O-Al. No obstante los resultados obtenidos en la Figura 6(a) desmienten esta hipótesis. Es decir, al disminuir la alcalinidad disminuyen las resistencias mecánicas. Lo que realmente esta ocurriendo es que un contenido insuficiente de álcalis retra-
NMR and FTIR data have confirmed that in the absence of soluble silica, the metastable, aluminium-rich gel (GEL 1) initially formed in highly alkaline media evolves with reaction time toward a more stable, silicon-rich phase (GEL 2) (32); silicon occupies different positions in the three-dimensional structure of this phase, in which $Q^{4}(3 A l)$ and $Q^{4}(2 A I)$ units prevail.

The presence of soluble silica during activation (usually in the form of sodium silicate) plays an important role in the microstructural development of these cements, which follows a pattern similar to what is observed in many types of vitreous materials: formation of a uniform, compact matrix with a low pore content (40). Moreover, an increase in the amount of soluble silica in the initial system induces a rise in the Si and Na contents in these cements $(41,42)$. While this does not appear to have any major impact on the mechanisms governing the reactions, it does clearly affect the chemistry of the phases involved in such reactions, their kinetics and, naturally, the properties of the end product.

In the study described here, the primary aim was to correlate the mechanical strength developed by an alkali-activated fly ash to the compositional modifications imposed on the initial system by the addition of different amounts of alkalis in the form of sodium hydroxide and soluble silica, essentially in the form of sodium silicate. Another initial objective was to interpret such correlations in terms of the mineralogical and microstructural differences observed in the materials synthesized.

Figure 5 relates the microstructure developed in the material (determined by the position of the T-O bond vibration band) to the composition of the various materials studied. Given a constant $\mathrm{SiO}_{2} / \mathrm{Al}_{2} \mathrm{O}_{3}$ ratio, the $\mathrm{T}-\mathrm{O}$ bond stretching band was observed to appear at higher frequencies with declining system alkalinity. This behaviour might initially be interpreted to be due to the formation of gels with a higher Si/Al ratio (37). If this assumption were correct, mechanical strength should rise with lower alkalinity, since Si-O-Si bonds are stronger than Si-O-Al bonds. The results obtained in Figure 6(a) belie this hypothesis, however, for mechanical strength declined with decreasing alkalinity. The actual explanation is that an insufficient alkali content retarded initial ash dissolution, as Figure 4(b) shows. Consequently, the shift in the T-O band with declining alkalinity was due to the presence in the samples of a higher proportion of 


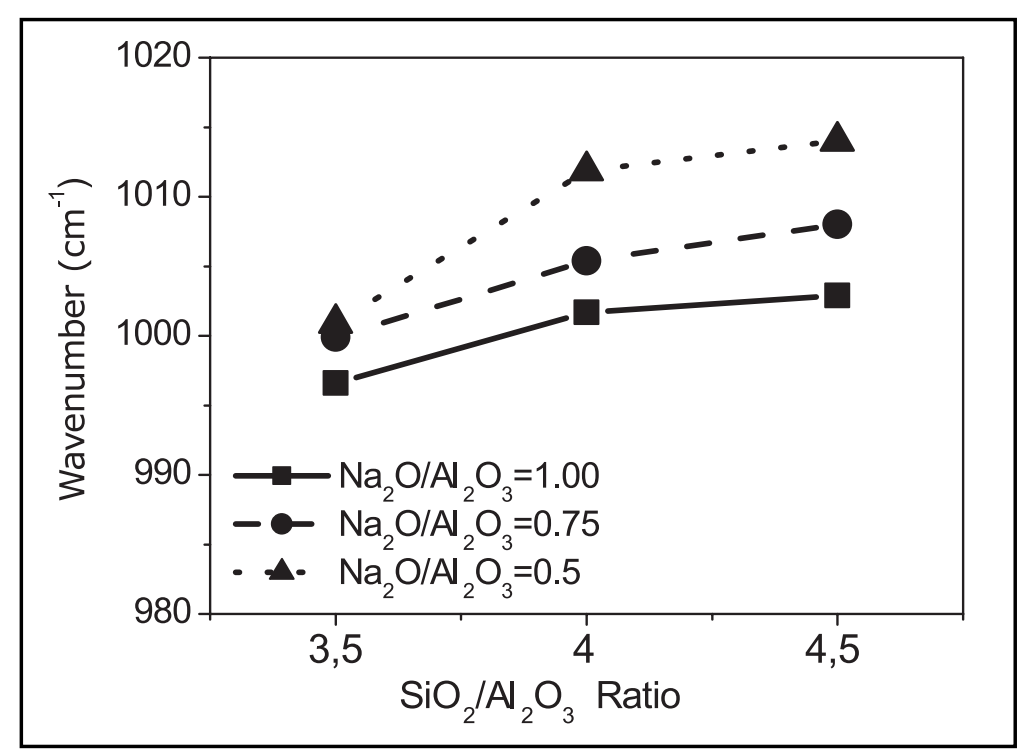

Figura 5. Desplazamiento de la banda de vibración T-O en función de la relación Si/Al del sistema de partida.

Figure 5. Shift in the T-O band versus the Si/Al ratio in the initial system.

sa los procesos iniciales de disolución de la ceniza, como se pone de manifiesto en la Figura 4(b). Por tanto, el desplazamiento de la banda de T-O al disminuir la alcalinidad se debe a la presencia en las muestras de un mayor contenido de ceniza sin reaccionar, no a la formación de geles con una mayor relación S/A. En la Figura 6(a) se observa claramente que las resistencias mecánicas aumentan cuando aumenta la relación $\mathrm{Na}_{2} \mathrm{O} / \mathrm{Al}_{2} \mathrm{O}_{3}$ desde 0,5 hasta 1,0; parece razonable pensar que la situación óptima en lo que respecta a la ratio $\mathrm{Na}_{2} \mathrm{O} / \mathrm{Al}_{2} \mathrm{O}_{3}$ es aquélla en la que existe el mismo número de átomos de $\mathrm{Na}$ que de $\mathrm{Al}$, dado que el Na compensaría el déficit de carga creado por la sustitución de un átomo de Si por Al.

En lo que respecta al ratio $\mathrm{SiO}_{2} / \mathrm{Al}_{2} \mathrm{O}_{3}$ los datos de la Figura 6(b) indican que no existe una relación de proporcionalidad lineal con el desarrollo de las resistencia mecánicas. En los materiales con los que se ha trabajado en esta investigación, las mejores resistencias mecánicas se obtienen para la ratio $\mathrm{SiO}_{2} / \mathrm{Al}_{2} \mathrm{O}_{3}=4$ y las peores para la ratio 4,5 (si bien es verdad que en este caso el curado fue diferente). Las resistencias mecánicas correspondientes a la composición con $\mathrm{SiO}_{2} / \mathrm{Al}_{2} \mathrm{O}_{3}=3,5$ ocupan un lugar intermedio. Son varias las causas que explican este comportamiento:

a) En lo que respecta al incremento de las resistencias observado cuando la relación $\mathrm{SiO}_{2} / \mathrm{Al}_{2} \mathrm{O}_{3}$ aumenta de 3 a 4 hay diferentes aspectos a considerar. Como estos materiales presentan grados de reacción similares (ver Fig. 4), las diferencias en su comportamiento mecánico deben estar relacionadas con la naturaleza y composición de los productos de reacción formados. Los datos obtenidos por DRX y FTIR indican que un mayor unreacted ash, and not to the formation of gels with a higher $S / A$ ratio. As clearly observed in Figure 6(a), mechanical strength grew when the $\mathrm{Na}_{2} \mathrm{O} / \mathrm{Al}_{2} \mathrm{O}_{3}$ ratio rose from 0.5 to 1.0; reasonably, then, the optimal $\mathrm{Na}_{2} \mathrm{O} / \mathrm{Al}_{2} \mathrm{O}_{3}$ ratio may be thought to be the one where the same number of $\mathrm{Na}$ and $\mathrm{Al}$ atoms are present, since the $\mathrm{Na}$ would offset the charge deficit generated by the replacement of Si by $\mathrm{Al}$ atoms.

The data in Figure $6(b)$, in turn, indicate that there is no proportional linear relationship between the $\mathrm{SiO}_{2} / \mathrm{Al}_{2} \mathrm{O}_{3}$ ratio and the development of mechanical strength. In the working materials used in this study, the highest strength values were obtained for a $\mathrm{SiO}_{2} / \mathrm{Al}_{2} \mathrm{O}_{3}$ ratio of 4 and the lowest for a ratio of 4.5 (although be it said that the respective specimens were cured differently). Intermediate mechanical strength values were found for the composition with a $\mathrm{SiO}_{2} / \mathrm{Al}_{2} \mathrm{O}_{3}$ ratio of 3.5. Several causes underlie these findings:

a) Three questions should be considered with respect to the increase in strength observed when the $\mathrm{SiO}_{2} / \mathrm{Al}_{2} \mathrm{O}_{3}$ ratio rises from 3 to 4 . Since these materials have similar degrees of reaction (see Figure 4), the differences in their strength performance must be related to the nature and composition of the reaction products formed. The XRD and FTIR data obtained indicate that more soluble silica in the system varied the proportion 
aporte de sílice soluble al sistema disminuye la cantidad de zeolitas formadas en favor del contenido de gel. En trabajos previos a través de difracción X aplicando el método Rietveld XRPD (34) se ha demostrado cuantitativamente que mayores contenidos de gel dan lugar a mayores resistencias mecánicas, dado que el material cementante es el precursor zeolitico (gel de aluminosilicato sódico) y no la zeolita. Además en la Figura 5 se observa que el incremento del contenido de sílice soluble provoca un desplazamiento de la banda de tensión de los enlaces T-O a frecuencias mayores. Como los sistemas $S / A=3$ y $S / A=4$ presentan grados de reacción similares, este desplazamiento se podría asociar a la formación de geles más ricos en sílice. Todo parece indicar que para relaciones $S / A=4$ se forma, además de una mayor cantidad de gel, un gel más rico en $\mathrm{Si}$, lo cual justifica los elevados valores de resistencia mecánica obtenidos con esta composición que pueden llegar a superar los $100 \mathrm{MPa}$.

b) Por el contrario, la razon del descenso de las resistencias mecánicas observado cuando la relación $\mathrm{SiO}_{2} / \mathrm{Al}_{2} \mathrm{O}_{3}$ sigue aumentando de 4 a 4,5 no es tan obvia, ya que para poder alcanzar relaciones $S / A=4,5$ hubo que realizar modificaciones en las variables de síntesis. En primer lugar para poder alcanzar dicha relación fue necesario adicionar al sistema humo de of end products, reducing the amount of zeolites and increasing the amount of gel. Earlier research in which $X R D$ patterns were refined with the Rietveld method (34) showed quantitatively that a higher gel content gives rise to higher strength, since the cementitious material is the zeolite precursor (sodium aluminosilicate gel) rather than the zeolite. Furthermore, as shown in Figure 5, increases in the soluble silica content prompted a shift in the $\mathrm{T}-\mathrm{O}$ bond stretching band to higher frequencies. Since the $S / A=3$ and $S / A=4$ systems had similar degrees of reaction, this shift can be associated with the formation of gels richer in silica. The findings indicate that at $S / A$ ratios of 4 , in addition to more gel, the gel formed is richer in Si, justifying the high values of mechanical strength obtained with this composition, which may exceed $100 \mathrm{MPa}$.

b) By contrast, the reason for the decline in mechanical strength observed when the $\mathrm{SiO}_{2} / \mathrm{Al}_{2} \mathrm{O}_{3}$ ratio was raised from 4 to 4.5 is less obvious, for in order to attain a $S / A$ ratio of 4.5 , the synthesis variables had to be modified. Firstly, silica fume had to be added to the system. While highly reactive, silica fume exhibits lower reactivity than the soluble silica present in the
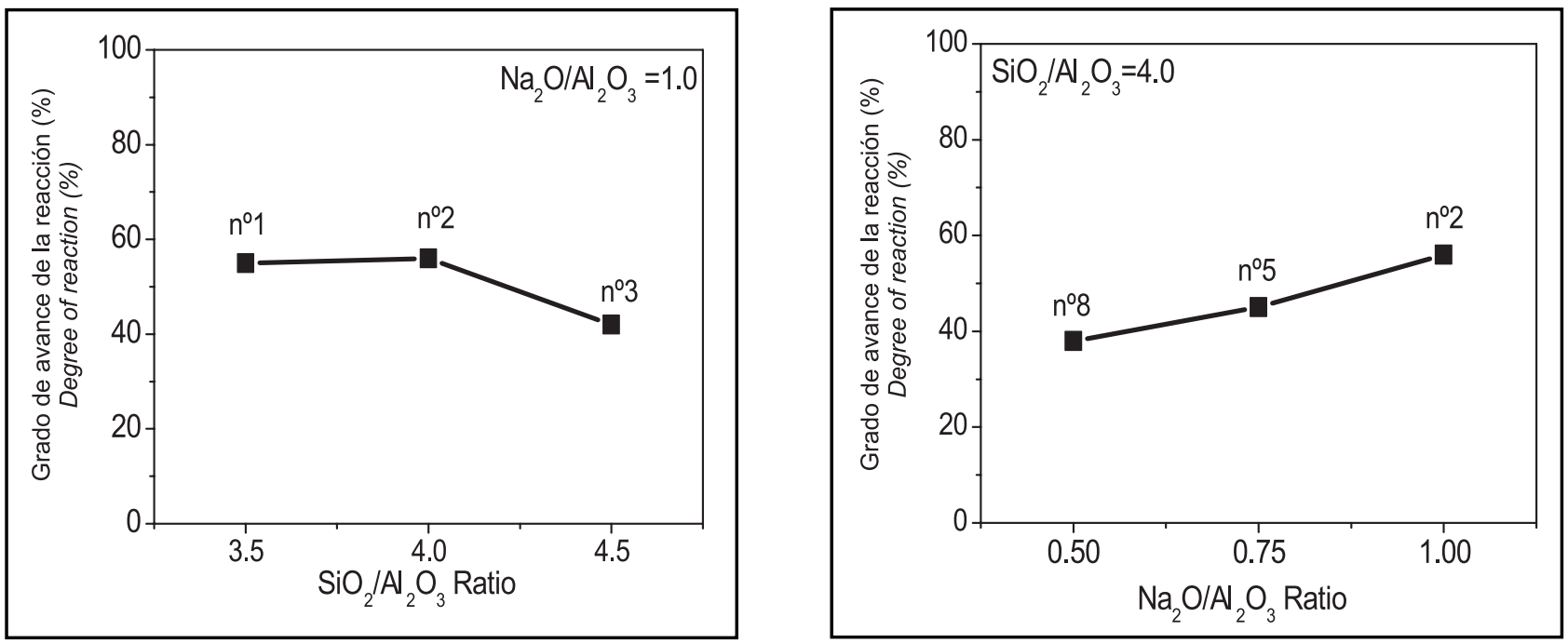

Figura 6. Evolución de las resistencias mecánicas a compresión en función de la relación (a) $\mathrm{Na}_{2} \mathrm{O} / \mathrm{Al}_{2} \mathrm{O}_{3}$ y (b) $\mathrm{SiO}_{2} / \mathrm{Al}_{2} \mathrm{O}_{3}$. Figure 6. Compression strength versus (a) the $\mathrm{Na}_{2} \mathrm{O} / \mathrm{Al}_{2} \mathrm{O}_{3}$ ratio and (b) the $\mathrm{SiO}_{2} / \mathrm{Al}_{2} \mathrm{O}_{3}$ ratio.

sílice. El humo de sílice si bien es un material muy reactivo, su reactividad es inferior a la de la sílice soluble presente en el waterglass empleado como activador. Por otra parte, para evitar fenómenos expansivos atribuidos a la reacción del humo de sílice (12) fue necesario disminuir la temperatura de curado a $65^{\circ} \mathrm{C}$. waterglass activator. Moreover, to avoid the expansion attributed to the silica fume reaction (12), the curing temperature had to be lowered to $65^{\circ} \mathrm{C}$. These modifications may be largely account for the lower degrees of reaction observed in these blends (see Figure 4). Such lesser degrees of reaction in turn justified the 
Estas modificaciones pueden ser, en gran medida, la causa de los menores grados de reacción que presentan estas mezclas (ver Figura 4). Menores grados de reacción que, a su vez, justifican los menores valores de resistencia mecánica obtenidos (ver Figura 6(b)), así como los mayores desplazamientos observados para la banda de tensión de los enlaces T-O en estas composiciones (ver Figura 5). No obstante, en este punto también hay que mencionar la existencia de trabajos previos $(32,41,42)$ donde se pone de manifiesto la posible existencia de un valor umbral en lo que respecta a la relación S/A en este tipo de materiales; valor a partir del cual la adición de proporciones mayores de sílice deja de tener un efecto beneficioso. En el presente trabajo es difícil concluir algo al respecto debido a las peculiaridades de las composiciones $\mathrm{S} / \mathrm{A}=4,5$.

\section{CONCLUSIONES}

La activación alcalina de cenizas volantes en condiciones de curado adecuadas (temperatura, humedad relativa, etc.) produce en periodos de tiempo relativamente cortos (pocas horas) materiales con unas muy elevadas prestaciones mecánicas. El principal producto de reacción que se forma en este proceso, y que es responsable del desarrollo mecánico del material, es un gel de aluminato sódico que posee una nanoestructura tridimensional muy similar a la que poseen las zeolitas. De ahí que dicho gel pueda ser considerado como un "precursor zeolitico".

Dependiendo de la composición del sistema de partida el material resultante desarrolla diferentes prestaciones mecánicas. Así:

- La relación $\mathrm{SiO}_{2} / \mathrm{Al}_{2} \mathrm{O}_{3}$ no varía de forma lineal con las resistencias mecánicas. En este trabajo los valores óptimos se encuentran en torno a relaciones molares comprendidas entre 3,5 y 4,0 . Valores superiores dan lugar a un brusco descenso de dichas resistencias mecánicas.

- La ratio $\mathrm{Na}_{2} \mathrm{O} / \mathrm{Al}_{2} \mathrm{O}_{3}$ es óptima cuando su valor es 1 ya que de esta manera se sabe que las cargas iónicas del $\mathrm{Al}^{3+}$ y del $\mathrm{Na}^{+}$compensan de forma equilibrada las sustituciones Si-Al en el esqueleto estructural. Cualquier desequilibrio en esa ratio puede tener efectos negativos en el desarrollo mecánico resistente del material.

En general, estos sistemas cementantes basados en la activación alcalina de cenizas volantes se muestran muy sensibles a las modificaciones composicionales lo que les otorga una muy interesante capacidad (flexibilidad) de adaptarse a diferentes aplicaciones. lower mechanical strength values obtained (see Figure $6(b))$, and the wider shifts observed for the T-O bond stretching band in these compositions (see Figure 5). Nonetheless, here also reference should be made to prior research $(32,41,42)$ that suggested the existence of a threshold value in the $S / A$ ratio in these materials, beyond which the addition of higher proportions of silica would cease to be beneficial. It is difficult to draw conclusions in this regard in the present study due to the peculiarities of the compositions having a $S / A$ ratio of 4.5 .

\section{CONCLUSIONS}

The alkali activation of fly ash under suitable conditions of temperature, relative humidity and so on yields materials with high mechanical strength in relatively short periods of time (a few hours). The main reaction product formed in this process, which accounts for mechanical development in the material, is a sodium aluminate gel. Due to the nanostructural similarities between this gel and zeolites, it can be regarded to be a "zeolite precursor".

The mechanical performance of the resulting material depends on the composition of the initial system:

- The $\mathrm{SiO}_{2} / \mathrm{Al}_{2} \mathrm{O}_{3}$ ratio does not vary linearly with mechanical strength. In this paper the optimal values were found for molar ratios of from 3.5 to 4.0 Higher values induced an abrupt decline in strength.

- At an optimal $\mathrm{Na}_{2} \mathrm{O} / \mathrm{Al}_{2} \mathrm{O}_{3}$ ratio of 1 , the sum of the charges on the $\mathrm{Al}^{3+}$ and $\mathrm{Na}^{+}$ions offset the $\mathrm{Si}-\mathrm{Al}$ net negative charges resulting from replacements in the structural skeleton. Any imbalance in this ratio may have adverse effects on mechanical strength development in the material.

The fact that cementitious systems based on the alkali activation of fly ash are as a rule very sensitive to compositional modifications ensures their adaptability (flexibility) to different applications. 


\section{AGRADECIMIENTOS}

Los autores desean agradecer al Comité Científico de la OTAN, por la beca postdoctoral concedida bajo el Science Fellowships Programme (2003) y que esta asociada con este estudio. Gracias también a la Dirección General de Investigación Científica por financiar proyecto BIA200628530-E; y al CSIC por el contrato I3P-PC2004L co-financiado por la Unión europea.

\section{ACKNOWLEDGEMENTS}

The authors wish to thank the NATO Scientific Committee for the postdoctoral grant under the NATO Science Fellowships Programme (2003) associated with this study. Thanks are also due to the Directorate General of Scientific Research for financing project BIA2006-28530$E$; and to the CSIC for co-financing European social contract REF. I3P-PC2004L.

\section{BIBLIOGRAFÍA / BIBLIOGRAPHY}

(1) Glukhovskiy, V.D.: Soil silicates. Gosstroy publsh, Kiev (1959). (in Russian).

(2) Glukhovskiy, V.D.: Soil-Silicate Articles and Constructions. Kyiv, Budivelnik publish, (1967). (in Ukrainian).

(3) Krivenko, P.V.: Alkaline Cements. Proceed. First Intern. Conf. "Alkaline cements and Concretes". Kiev, Vipol publish, pp.11-129, (1994).

(4) Krivenko, P.V.: Alkaline Cements: Terminology, Classification, Aspects of Durability. Proceed. Tenth Intern. Congress on the Chemistry of Cement, Göteborg, Sweden, p. 4iv046-4iv050 (1997).

(5) Davidovits, J. (ed.): Proceed. First European Conf. On Soft Mineralurgy "Geopolymer'88", Compiegne, (1988).

(6) Palomo, A., Grutzeck M.W., Blanco M.T.: "Alkali-activated fly ashes - A cement for the future" Cement and Concrete Research, 29 (8), pp.1323-1329, (1999). http://dx.doi.org/10.1016/S0008-8846(98)00243-9

(7) Hua Xu and Jannie S.J. van Deventer: "Effect of Source Materials on geopolymerization". Ind. Eng. Chem. Res. Vol 42, pp. 1698-1706 (2003). http://dx.doi.org/10.1021/ie0206958

(8) Rostovskaya, G., Illyin, V., and Brodko, O.: The investigation of Service Properties of the Slag Alkaline Concretes. Proceed. Intern. Symposium "Non-traditional Cement\&Concrete", Brno, pp.510-523, (2002).

(9) Chirkova, V.V.: Materials Based on Glass-Like Calcium-Free Aluminosilicates and Sodium Compounds. PhD Thesis, Kiev (1974). (in Russian).

(10) Krivenko, P.V., and Skurchinskaya, J.V.: Fly Ash Containing Geocements. Proceed. Intern. Conf. on the Utilization of Fly Ash and other Coal Combustion By-Products, Shanghai, pp. 64-1 - 64-7 (1991).

(11) Krivenko, P.V.: Fly Ash - Alkali Cements and Concretes. Proceed. 4th CANMET-ACI Intern. Conf. on Fly Ash, Silica Fume, Slag and Natural Pozzolans in Concrete, Istanbul pp. 721-734 (1992).

(12) Krivenko, P.V., and Kovalchuk, G.Yu.: Fly Ash Based Zeolite Cements. Innovations and Developments in Concrete Materials and Construction: Proceed. Intern. Conf. "Challenges of Concrete Construction", Dundee, pp. 123-132 (2002).

(13) Krivenko, P.V., and Kovalchuk, G.Yu.: Heat-Resistant Fly Ash Based Geocements. Proceed. Intern. Conf. "Geopolymers 2002", Melbourne (2002).

(14) Kovalchuk, G.Yu.: Heat Resistant Gas Concrete Based on Alkaline Aluminosilicate Binder. PhD Thesis, Kyiv (2002). (in Ukrainian)

(15) Palomo, A., Alonso, S., Fernández-Jiménez, A., Sobrados, I., Sanz, J.: "Alkaline Activation of Fly Ashes: NMR Study of the Reaction Products", J. Am. Ceram. Soc., 87, (6), pp. 1141-1145 (2004).

(16) Fernández-Jiménez, A., Palomo, A. and López-Hombrados, C.: "Some engineering properties of alkali activated fly ash concrete" ACI Materials Journal 103 (2) pp. 106-112 (2006).

(17) Fernández-Jiménez, A., Palomo, A., Criado, M.: "Alkali activated fly ash binders. A. comparative study between sodium and potassium activators". Mater. Construcc. 56, no 281, pp. 51-65 (2006).

(18) Duxson, P., Fernández-Jiménez, A., Provis, J.L., Lukey, G.C., Palomo, A., van Deventer J.S.J. "Geopolymer technology: The current state of the art. J. Materials Science, 42, pp. 2917-2933 (2007). http://dx.doi.org/10.1007/s10853-006-0637-z

(19) Duxson, P., Provis, J.L., Lukey, G.C., Mallicoat, S.W., Kriven W.M.: van Deventer J.S.J., "Understanding the relationship between geopolymer composition, microstructure and mechanical properties" Colloids and surfaces A, 269, pp. 47-58 (2005). http://dx.doi.org/ 10.1016/j.colsurfa.2005.06.060

(20) Buchwald, A., Schulz, M.: "Alkali-activated binders by use of industrial by-products" Cement and Concrete Research, 35, (5), pp.968973, (2005). http://dx.doi.org/10.1016/j.cemconres.2004.06.019

(21) Skvara, F., Slosar, J., Bohunek, J., and Markova, A.: Alkali-Aktivated Fly Ash Geopolymeric Materials. Proceed. 11th Intern. Congress on the Chemistry of Cement, Durban pp. 1341-1350 (2003).

(22) Van Jaarsveld, J.G.S., Van Deventer, J.S.J.: "Effect of the Alkali Metal Activator on the Properties of Fly Ash Based Geopolymers". Ind. Eng. Chem. Res. 38, no 10, pp. 3932-3941 (1999). http://dx.doi.org/10.1021/ie980804b

(23) Fernández-Jiménez, A., Palomo, A.: "Composition and microstructure of alkali activated fly ash binder: Effect of the activator", Cem. Con. Res., 35, pp.1984-1992 (2005). http://dx.doi.org/10.1016/j.cemconres.2005.03.003

(24) Kovalchuk, G., Fernández-Jiménez, A., Palomo, A.: "Alkali-activated fly ash: Effect of thermal curing conditions on mechanical and microstructural development-Part II" Fuel, 86, pp. 315-322 (2007). http://dx.doi.org/10.1016/j.fuel.2006.07.010

(25) Fernández-Jiménez, A., García-Lodeiro, I., and Palomo, A., "Durability of alkali-activated fly ash cementitions materials" J. Materials Science, 42, pp. 3055-3065 (2007). http://dx.doi.org/10.1007/s10853-006-0584-8 
(26) Caijun Shi, Fernández-Jiménez A.: "Stabilization/Solidification of Hazardous and Radioactive Wastes With Alkali-Activated Cements" J. Hazardous Materials. 11, pp. 1656-1663 (2006). http://dx.doi.org/10.1016/j.jhazmat.2006.05.008

(27) Criado M., Palomo A., Fernández-Jiménez A.: "Alkali activation of fly ashes. Part 1: Effect of curing conditions on the carbonation of the reaction products" FUEL, 84, pp.2048-2054 (2005). http://dx.doi.org/10.1016/j.fuel.2005.03.030

(28) Van Jaarsveld, J. G. S., van Deventer J. S. J. and Lorenzen, L.: "The potential use of geopolymeric materials to immobilise toxic metals, Part I. theory and applications", Minerals Engineering, 10, 659 (1996). http://dx.doi.org/10.1016/S0892-6875(97)00046-0

(29) Fernández-Jimenez A., de la Torre A.G., Palomo A., López-Olmo G., Alonso M. M. and Aranda M. A. G.: Quantitative determination of phases in alkaline activation of fly ashes. Part II the degree of reaction FUEL 85, pp. 1960-1969 (2006). http://dx.doi.org/10.1016/ j.fuel.2006.04.006

(30) Fernández-Jiménez, A., Palomo, A.: "Characterisation of fly ashes. Potential reactivity as alkaline cements", Fuel, 82, pp. 2259-2265, (2003). http://dx.doi.org/10.1016/S0016-2361(03)00194-7

(31) Fernández-Jiménez, A., de la Torre, A.G., Palomo, A., López-Olmo, G., Alonso, M.M., Aranda, M. A. G.: "Quantitative determination of phases in the alkali activation of fly ash. Part I. Potential ash reactivity", Fuel, 85, pp. 625-634 (2006). http://dx.doi.org/10.1016/ j.fuel.2005.08.014

(32) Fernández-Jiménez, A., Palomo, A., Sobrados, I., Sanz, J.: "The role played by the reactive alumina content in the alkaline activation of fly ashes", Microp. Mesop. Mat. 91, pp. 111-119 (2006). http://dx.doi.org/10.1016/j.micromeso.2005.11.015

(33) Querol, X., Alastuey, A., Lopez-Soler, A., Plana, F., Andres, J. M., Juan, R. Ferrer, P. and Ruiz, C. R.: "A fast method for recycling fly ash: microwave-assisted zeolite synthesis", Environmental Science and Technology, 31, pp. 2527- 2533 (1997). http://dx.doi.org/10.1021/ es960937t

(34) Criado M., Fernández-Jiménez A., de la Torre A.G., Aranda M.A.G. and Palomo A.: "An XRD study of the effect of the $\mathrm{SiO}_{2} / \mathrm{Na}_{2} \mathrm{O}$ ratio on the alkali activation of fly ash" Cement and Concrete Research, 37, pp. 671-679 (2007). http://dx.doi.org/10.1016/j.cemconres. 2007.01.013

(35) Barrer, R. M.: Hydrothermal Chemistry of Zeolites. Academic Press, London (1982).

(36) Breck D. W.: "Zeolita Molecular Sieves", Ed. Krieger (1974), Florida, EEUU.

(37) Fernández-Jiménez, A., Palomo, A.: "Mid-infrared spectroscopic studies of alkali-activated fly ash structure", Micro. and Mesoporous Mat., 86, pp. 207-214 (2005). http://dx.doi.org/10.1016/j.micromeso.2005.05.057

(38) Criado, M., Fernández-Jiménez, A. and Palomo, A.: "Alkali activation of fly ash. Effect of the $\mathrm{SiO}_{2} / \mathrm{Na}_{2} \mathrm{O}$ ratio. Part I. FTIR study", Microporous and mesoporous materials, 106, pp. 180-191 (2007). http://dx.doi.org/10.1016/j.micromeso.2007.02.055

(39) Mozgawa, W., Sitarz, M., Rokita, M.: "Spectroscopic studies of different aluminosilicate structures" J. Molecular Structure, 511-512, pp. 251-257 (1999). http://dx.doi.org/10.1016/S0022-2860(99)00165-9

(40) Palomo A., Fernández-Jiménez A., and Criado M.: "Geopolymers: one only chemical basis, some different microstructures" Mater Construcc, Vol. 54, no 275, pp. 77-91 (2004).

(41) Criado, M., Fernández-Jiménez, A., Palomo, A., Sobrados, I., and Sanz, J.: "Alkali activation of fly ash. Effect of the $\mathrm{SiO}_{2} / \mathrm{Na}_{2} \mathrm{O}$ ratio. Part II. ${ }^{29}$ Si NMR Survey " Microporous and mesoporous materials, 109, pp. 525-534 (2008). http://dx.doi.org/10.1016/j.micromeso.2007.05.062

(42) Lee, W. K. W., and Van Deventer, J. S. J.: "Structural reorganization of class F fly ash in alkaline silicate solutios", Colloids and Surfaces A: Physicochem Eng. Aspects. 211, pp. 49-66 (2002). http://dx.doi.org/10.1016/S0927-7757(02)00237-6 